\title{
Rumah Sehat Anti Stunting (RS - AS)
}

\author{
Anti Stunting Healthy Home (RS - AS)
}

\author{
Dyah Wiji Puspita Sari ${ }^{1^{*}}$, Apriliani Yulianti Wuriningsih ${ }^{1}$, Nopi Nur Khasanah ${ }^{1}$ \\ ${ }^{1}$ Fakultas Ilmu Keperawatan, Universitas Islam Sultan Agung \\ *daiyah_04@yahoo.com
}

\begin{abstract}
ABSTRAK
Ancaman permasalahan gizi di dunia, ada 165 juta anak dibawah 5 tahun dalam kondisi pendek (stunting) dan 90\% lebih berada di Afrika dan Asia. Pada kota Semarang khususnya di kelurahan penggaron lor terdapat banyak anak yang beresiko stunting. Metode yang digunakan untuk menjalankan kegiatan ini yaitu penyiapan (1) bahan baku, (2) produksi, (3) proses produksi, (4) manajemen, (5) SDM, (6) pemasaran, (7) fasilitas, dan (8) finansial. Hasil pelaksanaan kegiatan pengabdian masyarakat pada skim PPUPIK ini telah menghasilkan keuntungan yang besar dari hasil layanan RS-AS serta mampu menurunkan angka kejadian stunting yang dibuktikan dari hasil observasi di Posyandu Wilayah Kerja Puskesmas Bangetayu didapatkan data 12 dari 38 baduta (30\%) memiliki hasil skor $<-2$ SD (stunting), sedangkan studi awal menyebutkan terdapat sekitar 34\% baduta mengalami stunting. Kegiatan PPUPIK yang dilakukan melalui RS AS telah berhasil menekan peningkatan angka kejadian stunting terutama di wilayah kerja Puskesmas Bangetayu. Pengembangan RS AS perlu dilakukan untuk menjawab antusiasme warga masyarakat yang berada di sekitar kampus Unissula.
\end{abstract}

Kata kunci — rumah sehat, anti stunting, stunting

\begin{abstract}
The threat of nutritional problems in the world, there are 165 million children under 5 years in a short condition (stunting) and 90\% more are in Africa and Asia. In the city of Semarang, especially in the village of Penggaron lor, there are many children who are at risk of stunting. The method used to carry out this activity is the preparation of (1) raw materials, (2) production, (3) production processes, (4) management, (5) HR, (6) marketing, (7) facilities, and (8) financial. The results of the implementation of community service activities in the PPUPIK scheme have resulted in large profits from the results of US-RS services and were able to reduce the incidence of stunting as evidenced by observations at the Posyandu in the Work Area of the Bangetayu Health Center, data obtained from 12 out of 38 children (30\%) had a score $<-2$ SD (stunting), while the initial study stated that around $34 \%$ of children under two were stunted. PPUPIK activities carried out through the AS Hospital have succeeded in reducing the increase in the incidence of stunting, especially in the work area of the Bangetayu Health Center. The development of the AS Hospital needs to be done to answer the enthusiasm of the community around the Unissula campus.
\end{abstract}

Keywords - anti stunting, healthy house, stunting 


\section{Pendahuluan}

Ancaman permasalahan gizi di dunia, ada 165 juta anak di bawah 5 tahun dalam kondisi pendek (stunting) dan 90\% lebih berada di Afrika dan Asia. Target global adalah menurunkan Stunting sebanyak $40 \%$ pada tahun 2025 (Kementrian Kesehatan RI, 2016 [14]). Untuk itu dibutuhkan penurunan 3,9\% per tahun. Dalam jangka waktu 20 tahun tersebut dapat diturunkan $1,6 \%$ per tahun. Penurunan yang cukup besar terjadi di Asia (dari 49\% menjadi $28 \%$ ), sekitar $2,9 \%$ per tahun. Penurunan yang terbesar ada di Tiongkok, pada tahun 1990 sebesar 30\% menjadi $10 \%$ pada tahun 2011 .

Hasil dari South East Asian Nutrition Survey (SEANUTS) pada tahun 2010-2011 menempatkan Indonesia sebagai negara yang memiliki jumlah anak balita pendek terbesar, jauh di atas Malaysia, Thailand serta Vietnam (Union, The, International, \& Consortium, 2014 [16]). Status gizi balita Jawa Tengah tahun 2017 berdasar PSG : Balita gizi kurang (17\%), Balita pendek (28,5\%), Balita kurus (9,3\%) (Profil Kesehatan Provinsi Jawa Tengah, 2016 [14]).

Masalah stunting salah satunya dipengaruhi oleh status gizi ibu dan anak. Status gizi dan kesehatan ibu pada masa pra-hamil, saat kehamilannya dan saat menyusui sejak 1000 hari pertama kehidupan (HPK) merupakan periode yang sangat kritis. Kekurangan gizi kronik pada 1000 HPK akan berdampak pada gangguan pertumbuhan fisik yaitu salah satunya stunting, hingga berdampak pada kualitas kerja yang tidak kompetitif yang berakibat pada rendahnya tingkat pendapatan dan kesejahteraan masyarakat (Kementerian Koordinator Bidang Kesejahteraan Rakyat, 2013) [10]. Masalah kekurangan gizi atau stunting disebabkan oleh banyak faktor.

Berbagai bukti ilmiah dari lembaga riset gizi dan kesehatan terbaik di dunia menunjukkan bahwa faktor penyebab terpenting stunting adalah lingkungan hidup sejak konsepsi sampai anak usia 2 tahun yang dapat diubah dan diperbaiki dengan fokus pada masa 1000 HPK (Barker \& Thornburg, 2013 [4]). Bukan karena faktor utama yaitu faktor genetik seperti anggapan masyarakat pada umumnya. Masalah gizi merupakan akibat dari berbagai faktor yang saling terkait. Terdapat dua faktor langsung yang mempengaruhi status gizi individu. Faktor penyebab langsung pertama adalah konsumsi makanan yang tidak memenuhi jumlah dan komposisi zat gizi yang memenuhi syarat gizi seimbang yaitu beragam, sesuai kebutuhan, bersih, dan aman, misalnya bayi tidak memperoleh ASI Eksklusif. Faktor penyebab langsung kedua adalah penyakit infeksi yang berkaitan dengan tingginya kejadian penyakit menular terutama diare, cacingan dan penyakit pernapasan akut (ISPA) (Kementerian Koordinator Bidang Kesejahteraan Rakyat, 2013 [10]).

Masalah stunting akan terus terjadi apabila tidak ada perbaikan gizi dan pelayanan kesehatan yang memadai pada masa-masa 1000 HPK. Pentingnya pemenuhan gizi pada kelompok 1000 HPK akan mengurangi jumlah anak pendek di generasi yang akan datang dan seterusnya (Ahmed, Rahman Khan, \& Jackson, 2001 [2]; International Food Policy Research Institute, 1999 [7]; ).

Hasil studi pendahuluan yang dilakukan di Kelurahan Penggaron Lor khususnya di RW 1 didapatkan data bahwa jumlah penduduk terdiri dari 5990 dengan jumlah KK 1547 dan jumlah penduduk perempuan 2857 orang (Data Demografi Kel Penggaron Lor, 2018 [13]). Berdasarkan hasil penyebaran kuesioner terkait masalah stunting didapatkan data bahwa pengetahuan ibu untuk memilih makanan dengan kadar gizi seimbang masih kurang $(28,6 \%)$, Pengetahuan ibu tentang keteraturan meminum tablet Fe masih kurang $(34,3 \%)$ dan pengetahuan ibu mengenai pemberian program tablet Fe dari puskesmas masih kurang (28,6\%). Pengetahuan ibu mengenai pemberian MP-ASI masih kurang (31,4\%), Pengetahuan ibu untuk membawa balitanya ke posyandu masih kurang $(57,1 \%)$, Kepercayaan ibu mengenai makanan saat hamil masih kurang $(26,67 \%)$, Ibu menganggap menyusui memiliki efek samping terhadap perubahan payudaranya $(40 \%)$, Sikap ibu terhadap porsi makan saat hamil masih kurang $(31,4 \%)$, Sikap ibu membawa ke posyandu setelah imunisasi lengkap masih kurang $(34,3 \%)$, Tidak memberikan ASI eksklusif (11,1\%), Tidak menimbang balita satu bulan terakhir $(48,7 \%)$, Tidak memberikan imunisasi lengkap $(37,5 \%)$. 
Salah satu upaya perbaikan dalam menangani masalah stunting adalah melalui pembentukan Rumah Sehat Anti Stunting. Rumah Sehat Anti Stunting berada dalam area kampus Unissula yang dekat dengan Kelurahan Penggaron Lor. Rumah Sehat Anti Stunting berfokus dalam upaya pencegahan stunting pada anak. Kampus Unissula dekat dengan Lingkungan Industri Kecil (LIK), perumahan penduduk, instansi perkantoran maupun Rumah Sakit, oleh karena itu pemilihan lokasi ini sangat strategis untuk dikembangkan.

Sarana dan prasarana yang telah ada juga semakin mengoptimalkan program Rumah Sehat Anti Stunting. Adapun program yang ditawarkan, antara lain 1) jasa konsultasi gizi ibu hamil dan anak, 2) jasa konsultasi tumbuh kembang anak, 3) jasa pemeriksaan ante natal care (ANC) pada ibu hamil, 4) jasa pengolahan MP ASI untuk anak usia 6 - 23 bulan, 5) jasa pijat laktasi pada ibu menyusui, 6) jasa deteksi dini gangguan pertumbuhan dan perkembangan anak, 7) jasa baby SPA dan pijat bayi, 8) jasa stimulasi perkembangan, dan 9) jasa pengelolaan kebun gizi. Sarana dan prasarana yang dimiliki untuk mendukung usaha Rumah Sehat Anti Stunting antara lain adalah gedung Nursing Skill Laboratory. Di dalam gedung dua lantai ini terdapat beberapa ruang yang dapat digunakan dalam mendukung program PPUPIK ini.

\section{Target dan Luaran}

Target luaran dalam kegiatan PPUPIK ini adalah terbentuknya rumah anti stunting, pencegahan stunting, penurunan angka kejadian stunting, peningkatan pemahaman masyarakat dalam pencegahan stunting, gerakan anti stunting pada masyarakat mitra, dan perbaikan tata nilai masyarakat bidang kesehatan dalam pencegahan stunting.

\section{Metodologi}

Metode dalam pelaksanaan pengabdian masyarakat di bidang pengembangan usaha produk intelektual kampus ini dilakukan dalam delapan (delapan) tahapan, yaitu penyiapan (1) bahan baku, (2) produksi, (3) proses produksi, (4) manajemen, (5) SDM, (6) pemasaran, (7) fasilitas, dan (8) finansial. Penggunaan 8 metode ini efektif digunakan untuk menjalankan usaha rumah sehat anti stunting yang merupakan fasilitas layanan kesehatan bagi masyarakat.

\subsection{Bahan baku}

Regenerasi kehidupan di harapkan mampu meningkatkan pangsa pasar dari jasa ini. Masalah stunting yang semakin banyak, akan menyadarkan setiap individu untuk memberikan perawatan yang terbaik untuk anaknya. Pangsa pasar untuk bayi dan anak cukup tinggi di daerah Semarang. Lokasi kegiatan yang berdekatan dengan lingkungan penduduk, instansi pendidikan, rumah sakit dan perkantoran menjadikan layanan ini strategis untuk dikembangkan.

\subsection{Produksi}

Dalam dimensi ini, tim pengabdi berupaya agar praktik keperawatan tetap berjalan dengan baik. Tim pengabdi menyediakan Standar Operasional Prosedur tindakan (SOP), Form dokumentasi keperawatan, panduan stimulasi pertumbuhan dan perkembangan anak, buku panduan pijat bayi dan spa, buku panduan pijat laktasi, grafik KMS, form Denver II, serta tiket masuk area stimulasi perkembangan. Beberapa peralatan penunjang juga dibutuhkan untuk digunakan dalam setiap program, diantaranya nursing kit, alat habis pakai, alat stimulasi tumbuh kembang, kolam bayi untuk spa bayi dan anak, alat spa bayi dan pijat ibu. Selain itu, Meja kantor set komputer, tempat tidur ibu, bayi, dan anak, AC. Timbangan alat ukur tinggi badan dan berat badan, buku catatan perkembangan anak, dan fasilitas tumbuh kembang juga diperlukan. Letak lokasi kegiatan PPUPIK telah dipersiapkan dekat dengan jalan raya sekitar $300 \mathrm{~m}$ dan berada di dekat perkampungan penduduk, instansi perkantoran, SLTA, kantor kelurahan menjadikan Rumah Sehat - Anti Stunting mudah diakses. Status lahan berupa wakaf, bangunan dan perabotan seperti AC, peralatan kantor (meja dan kursi), peralatan dapur yang dapat digunakan sebagai penunjang kegiatan PPUPIK. 


\subsection{Proses produksi}

Kegiatan/program Rumah Sehat Anti Stunting membuka layanan di gedung skill laboratory lantai 2 dengan jadwal pelayanan yang dilakukan setiap hari Senin sampai Jumat, pada pukul 09.00 - 15.00 WIB. Proses dilakukan sesuai alur yaitu dari pendaftaran dilanjutkan dengan pemberian layanan sesuai kebutuhan pelanggan dilanjutkan dengan pendokumentasian hingga berakhir dengan laporan hasil

\subsection{Manajemen}

a. Perencanaan : dimulai dengan menyusun RAB, pengadaan sumber daya, penyusunan SOP pelaksanaan. Perencanaan pemasaran, perencanaan monitoring dan evaluasi.

b. Pelaksanaan : pelaksanaan kegiatan dimulai dari kegiatan promosi dari web dan brosur yang disebar ke institusi, sekolah dan masyarakat sekitar lokasi. Setelah pelayanan dilanjutkan dengan pelaksanaan layanan RSAS yang terdiri dari 9 layanan. Setiap tahunnya pelayanan akan berkembang dan akan dilakukan penambahan staf dan target klien. Pencatatan, pembukuan dilakukan oleh sekretaris bagian administrasi dan bendahara pada bagian keuangan. Audit dilakukan oleh ketua setiap satu bulan sekali untuk dilaporkan kepada Penanggung Jawab.

c. Evaluasi : dilakukan supervisi setiap satu bulan sekali, rapat koordinasi setiap 1 bulan sekali guna membahas kendala kendala yang dihadapi, dan mencari solusinya. Evaluasi dilakukan secara terjadwal yaitu evaluasi 3 bulanan, satu tahunan, dan evaluasi akhir kegiatan. Proses evaluasi meliputi evaluasi rencana produksi dan evaluasi keuangan, serta perpajakan dalam proses ini akan dibantu tim mutu baik audit internal maupun audit eksternal berupa audit keuangan dan perpajakan dari Fakultas Ilmu Keperawatan Unissula.

\subsection{Pemasaran}

Pemasaran dilakukan semua petugas baik melalui brosur, internet (webbsite), presentasi ke kantor kantor, lingkungan warga sekitar, sekolah dan rumah sakit.

\section{6. $\mathrm{SDM}$}

SDM dalam jasa ini antara lain Manajer (ketua), koordinator (sekretaris dan bendahara), 3 pelaksana dalam bidang pendidikan anak, kesehatan anak, dan sarana prasarana.

\subsection{Fasilitas}

Fasilitas yang diperlukan antara lain :Gedung yang terdiri dari 5 ruangan dan play ground. Akses ke jalan raya $300 \mathrm{~m}$. Fasilitas area tumbuh kembang lengkap, baby spa, pijat bayi, hidroterapy, pemeriksaan ANC lengkap, serta tenaga profesional.

\subsection{Finansial}

Secara finansial, setiap tahun akan ditentukan target capaian keuntungan usaha yang terus meningkat setiap tahunnya. Gambaran alur kas kegiatan ini pertahunya akan mengalami peningkatan keuntungan searah dengan pengembangan kegiatan dan target sasaran. Sesuai dengan permasalahan dan kebutuhan mitra, maka pelaksana pengabdian kepada masyarakat ini telah membentuk Tim yang terdiri dari ketua dan anggota yang memiliki kepakaran yang diperlukan dalam menyelesaikan seluruh persoalan atau kebutuhan mitra.

\section{Pembahasan}

Kegiatan pengabdian kepada masyarakat yang merupakan program unggulan produk intelektual kampus (PPUPIK) ini telah melaksanakan program layanan yang berfokus pada usaha Rumah Sehat Anti Stunting (RS-AS). RS-AS bergerak pada jasa layanan kesehatan dengan program-program pencegahan terjadinya risiko stunting pada anak. Pelayanan ini telah berlangsung sejak bulan April 2019. Sumber daya manusia pelaksana layanan ini di motori oleh tenaga kesehatan profesional pada bidang manajemen keperawatan, spesialis keperawatan anak, dan spesialis keperawatan maternitas serta melibatkan mahasiswa keperawatan.

Pelayanan RS-AS dilaksanakan di Gedung Nursing Skill Laboratory Fakultas Ilmu Keperawatan lantai 2. Rumah Sehat Anti Stunting ini difasilitasi oleh berbagai ruangan dan peralatan yang mendukung treatment pertumbuhan dan perkembangan pada anak serta 
treatment anti-stunting lainnya. Ruangan yang dimiliki RS-AS diantaranya Ruang spa atau pijat bayi dan pijat laktasi yang berisi kolam renang untuk balita dan peralatan pijat untuk pijat bayi dan pijat laktasi, serta berbagai mainan untuk menunjang proses baby spa. Ruang konseling digunakan untuk proses pelayanan konseling ahli untuk ibu megkonsultasikan mengenai pelayanan yang akan diambil di Rumah Sehat Anti Stunting, ruang ANC (Antenatal Care) untuk ibu hamil dalam mengkonsultasikan kandungannya yang berisi berbagai peralatan penunjang maternity. Ruang pengolahan MP-ASI untuk proses pelatihan dan demo masak pembuatan MP-ASI, ruangan ini berisi kompor, peralatan masak, dan peralatan penunjang lainnya. Dan ruang pengelola yang berisi rekam medis dan data klien Rumah Sehat Anti Stunting baik data dari kader kesehatan peduli stunting, ibu hamil, maupun balita dan ibu balita.

Pelaksanaan kegiatan pengabdian masyarakat ini diawali dengan berbagai kegiatan promosi atau pemasaran. Pemasaran adalah suatu proses dan manajerial yang membuat individu atau kelompok mendapatkan apa yang mereka butuhkan dengan menciptakan, menawarkan produk yang bernilai mulai dari produsen sampai konsumen (Basu, Swastha, Irawan, 2008) [15]. Pemasaran layanan RS-AS dilakukan melalui berbagai media seperti brosur, internet (webbsite) dengan membuat facebook, instagram, whats app, presentasi ke beberapa instansi pendukung seperti puskesmas, lingkungan warga sekitar, dan rumah sakit.

Kegiatan pemasaran juga dilaksanakan dengan kegiatan sosialisasi ke para petugas survey kesehatan (Gasurkes) dan para kaderkader kesehatan posyandu di bawah binaan Puskesmas Bangetayu mengenai program layanan Rumah Sehat Anti Stunting. Gasurkes dan kader kesehatan adalah Gasurkes dan kader kesehatan memiliki peran yang besar dalam memfasilitasi masyarakat dalam mencegah stunting. Gasurkes yang memiliki program utama pada kelas ibu hamil dan kader posyandu dengan program binaan posyandu balita, menjadi sarana yang efektif untuk mempromosikan layanan RS-AS. Pemasaran pada bagian ini tepat sasaran karena sesuai subjek sasaran layanan RSAS yaitu ibu hamil dan ibu yang memiliki anak baduta.

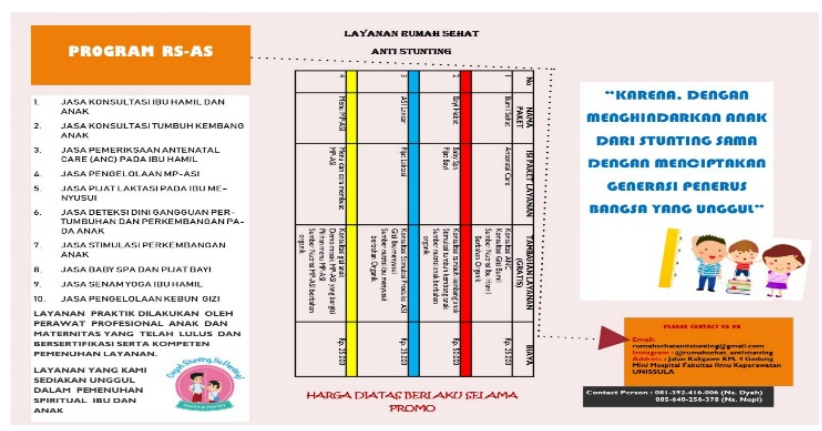

Gambar 1. Kegiatan pemasaran layanan RS-AS melalui brosur

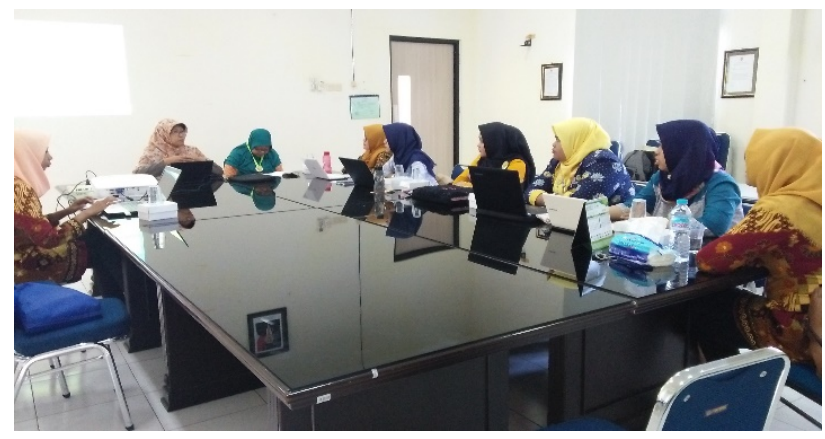

Gambar 2. Kegiatan pemasaran layanan RS-AS melalui sosialisasi ke Gasurkes

Hasil dari berbagai model pemasaran ini sangat efektif untuk menarik konsumen. Hal ini ditunjukkan dengan banyaknya konsumen layanan RS-AS yang mengetahui layanan RS-AS dari hasil berbagai model pemasaran yang telah dilakukan.

Kegiatan pemasaran yang telah berhasil dengan baik berdampak pada banyaknya animo permintaan layanan RS-AS. Layanan RS-AS terdiri dari 9 layanan yang meliputi 1) jasa konsultasi gizi ibu hamil dan anak, 2) jasa konsultasi tumbuh kembang anak, 3) jasa pemeriksaan ante natal care (ANC) pada ibu hamil, 4) jasa pengolahan MP ASI untuk anak usia 6 - 23 bulan, 5) jasa pijat laktasi pada ibu menyusui, 6) jasa deteksi dini gangguan pertumbuhan dan perkembangan anak, 7) jasa baby SPA dan pijat bayi, 8) jasa stimulasi perkembangan, dan 9) jasa pengelolaan kebun gizi.

Baby SPA dan pijat bayi merupakan bentuk stimulasi taktil/sentuhan pada bayi (Adriana, 2011) [1]. Stimulasi ini jika tidak didapatkan oleh bayi secara adekuat akan menyebabkan masalah penyimpangan perilaku sosial, emosional, dan motorik. Oleh karena itu, dalam pelaksanaan layanan RS AS, tim anak juga 
mengajarkan pada ibu agar dapat melakukan pijat bayi secara mandiri di rumah. Berdasarkan hasil kegiatan, banyak ibu bayi yang menyampaikan bahwa merasa takut untuk memijat bayinya sendiri, sehingga menyerahkan pada dukun bayi. Padahal, tujuan utama dari pijat bayi adalah adanya stimulasi taktil/sentuhan yang dirasakan oleh bayi, sehingga jika bayi mendapatkan sentuhan dari ibunya maka ikatan/bonding antara ibu dan bayi semakin kuat, selain itu bayi akan merasakan nyaman yang lebih jika mendapatkan sentuhan baik dari ibunya maupun ayahnya.

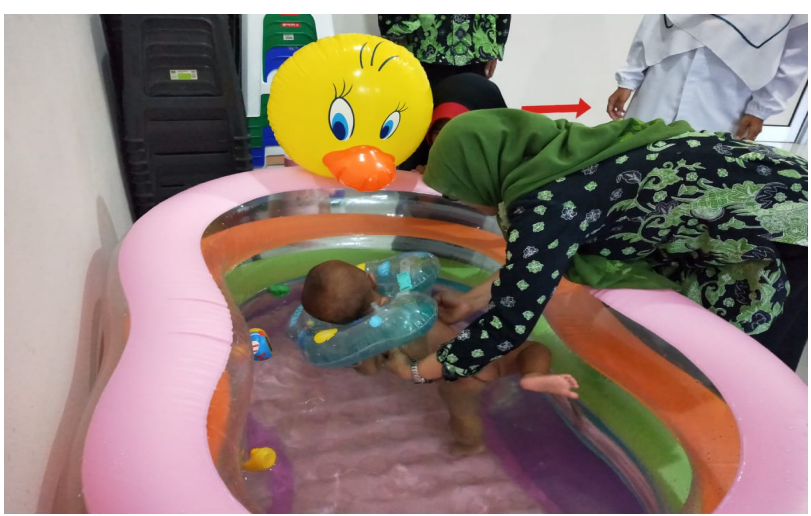

Gambar 3. Layanan jasa baby SPA dan pijat bayi

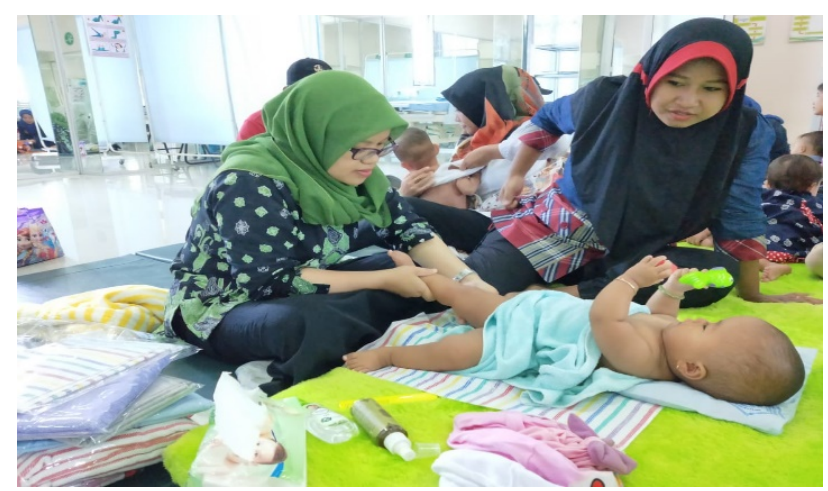

Gambar 4. layanan jasa baby SPA dan pijat bayi

Pemeriksaan ANC pada ibu hamil merupakan treatment yang penting dilakukan oleh setiap ibu hamil, terutama pada ibu hamil yang masuk trimester III. Pemeriksaan yang dilakukan secara rutin mampu mendeteksi secara dini jika terdapat hal yang memerlukan tindakan segera. Pada ibu hamil yang memiliki risiko tinggi seperti hyperemesis, hipertensi, maupun diabetes perlu mendapatkan pemantauan khusus dari petugas kesehatan. Ibu hamil dengan risiko tinggi dapat melahirkan bayi prematur, dimana bayi yang lahir prematur cenderung memiliki keterlambatan dalam tumbuh kembangnya jika tidak mendapatkan stimulasi yang sesuai dengan usianya.

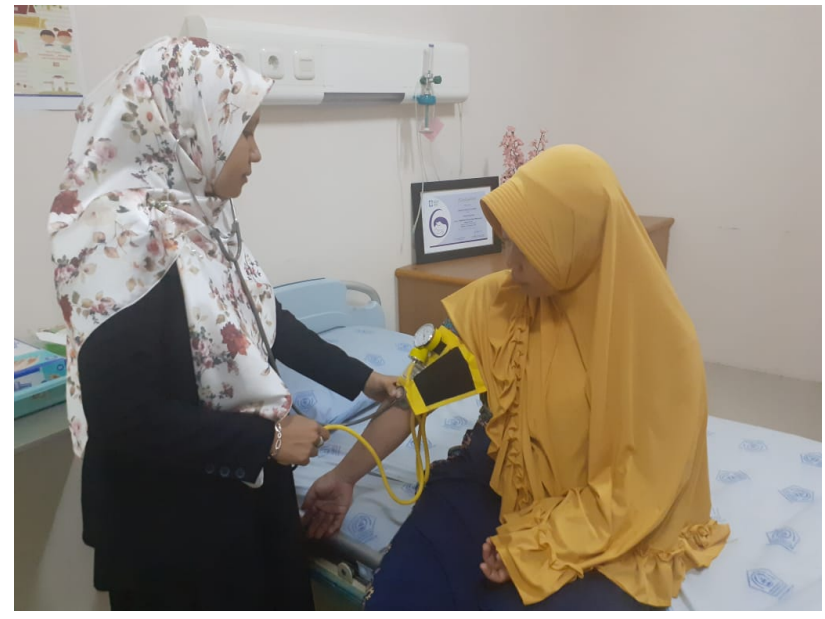

Gambar 5. Jasa pemeriksaan ante natal care (ANC) pada ibu hamil

Pemeriksaan ANC yang dilakukan di RS AS juga bertujuan untuk meningkatkan pemahaman ibu hamil tentang pencegahan stunting. Hal tersebut karena berdasarkan riset sebelumnya yang menyebutkan bahwa pengetahuan ibu, pendapatan keluarga, serta tingkat kecukupan zat besi dan zink dapat mempengaruhi terjadinya stunting (Aridiyah, Rohmawati, \& Ririanty, 2015; Astuti, 2016) [3].

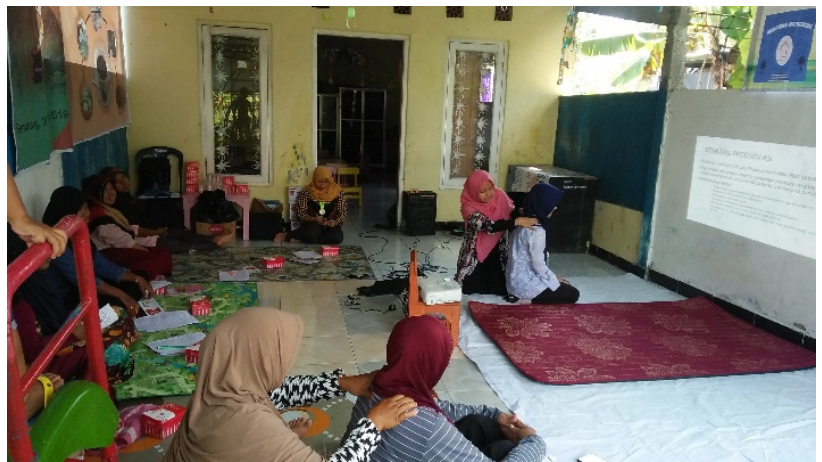

Gambar 6. Layanan jasa pijat laktasi pada ibu menyusui

Pijat laktasi merupakan metode perawatan payudara yang bertujuan untuk meningkatkan produksi ASI pada ibu pre dan post partum. Pijat laktasi sangat baik dilakukan untuk persiapan menyusui. Engebretsen et al (2014) [5]; Robert, Coppieters, Swennen, \& Dramaix (2014) [9] 
menyatakan bahwa World Health Organisation (WHO) sejak 2001 merekomendasikan pemberian ASI eksklusif untuk enam bulan pertama kehidupan dan terus menyusui sampai 2 tahun hidup. Manfaat yang jelas dari ASI baik untuk anak dan Ibu. Pemberian ASI eksklusif dapat mencegah $8 \%$ dari kematian anak di bawah usia 36 bulan dan $10-15 \%$ terhadap pertumbuhan terhambat. Berdasarkan hasil penelitian menyusui secara eksklusif selama 6 bulan dibandingkan dengan selama 3 sampai 4 bulan mengakibatkan morbiditas diare lebih rendah, mencegah amenorea laktasi yang berkepanjangan dan tidak ada pertumbuhan yang terhambat pada bayi baik yang berada di negara berpenghasilan rendah atau tinggi.

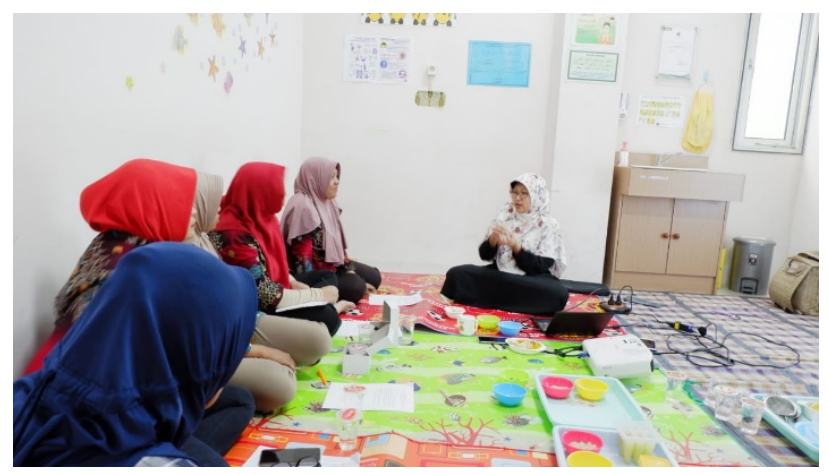

Gambar 7. Jasa pengolahan MP-ASI

MP-ASI diberikan pada anak mulai usia 6 bulan (Mufida, Widyaningsih, \& Maligan, 2015 [11] dan harus memenuhi pedoman gizi seimbang [8]). Menurut penelitian yang dilakukan Nova dan Afriyanti (2018) [12] menyebutkan bahwa terdapat hubungan yang signifikan pada variabel pemberian MP-ASI terhadap stunting, dan terdapat hubungan yang tidak signifikan pada Jenis MP-ASI, konsistensi MP-ASI terhadap stunting. Sementara itu, Imtihanatun dkk (2013) [6] menyebutkan bahwa bayi di bawah dua tahun (Baduta) dan bayi di bawah tiga tahun (Batita) yang mendapatkan MP-ASI tidak sesuai memiliki risiko 7,4 kali mengalami stunting dibandingkan dengan baduta dan balita yang mendapatkan MP-ASI sesuai. Oleh karena itu, tim berupaya untuk memberikan edukasi serta praktek secara langsung bagaimana pengolahan MP ASI sesuai dengan usia bayi.

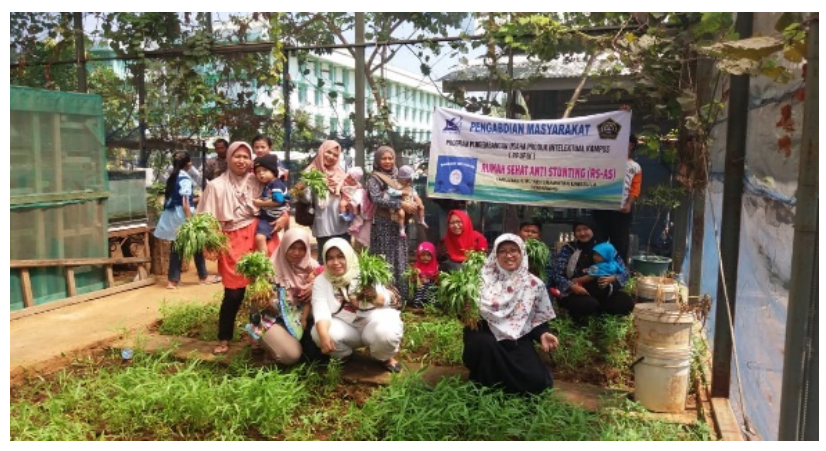

Gambar 8. Layanan Nutrisi Organik di Kebun Gizi

Pengelolaan kebun gizi merupakan layanan yang tidak kalah penting dengan layanan lainnya. Hal ini karena semangat tim adalah melakukan pencegahan stunting melalui pemenuhan gizi pada ibu hamil maupun baduta. Sehingga, tim memiliki semangat untuk memberikan layanan nutrisi organic bagi warga yang berkunjung ke RS AS. Setiap kunjungan diawali dengan wisata kebun gizi sebelum akhirnya mendapatkan layanan di RS AS. Kebun gizi ini berada di dalam kampus Unissula, dimana kebun gizi ini merupakan hasil kerjasama dengan kebun qur'an yang dimiliki oleh Yayasan badan Wakaf Sultan Agung (YBWSA). Para pengunjung diperbolehkan memetik sendiri berbagai sayuran organik yang sudah siap petik. Selain itu sebagai bentuk promosi di awal kunjungan, tim juga memberikan paket nutrisi organik sebagai bekal untuk membuat menu MP ASI saat di rumah.

Hasil evaluasi kepuasan penggunaan layanan ini menunjukkan 95\% pengguna menyatakan puas dan 5\% pengguna menyatakan cukup puas. Kepuasan ini dilihat dari lima aspek yang terdiri dari tangibles, responsibility, responsiveness, assurance, dan empathy (Basu, Swastha, Irawan, 2008) [15].

Selain itu hasil evaluasi dari kegiatan layanan RS-AS juga dilakukan melalui pemberian pre test dan post test pada konsumen layanan RS-AS. Sebelum pemberian materi, konsumen layanan RS-AS diberikan pre test mengenai motivasi dan stunting. Dilanjutkan dengan pemberian materi dan pelatihan dan diakhiri dengan post test. Dengan adanya pre test diharapkan dapat menjadi tolak ukur untuk melihat motivasi dan kemampuan awal konsumen layanan RS-AS dalam merawat serta 
memantau anaknya dalam hal pemenuhan gizi, pertumbuhan dan pekembangan. Hasil pre test menunjukkan hampir seluruh konsumen layanan RS-AS memahami tentang $15 \%$ cara-cara menghidarkan anak dari stunting. Para konsumen layanan RS-AS sudah bisa melakukan pemantauan pertumbuhan anak dengan pengukuran berat badan dan tinggi badan, namun mereka juga mengatakan belum bisa melakukan beberapa hal terkait treatment anti stunting yang sudah pengelola RS-AS sampaikan sebelumnya seperti stimulasi tumbuh kembang anak, pijat laktasi, menu dan cara membuat MP-ASI yang tepat, serta cara melakukan pijat bayi yang benar. Setelah dilaksanakan proses pendampingan oleh TIM RS-AS, kemampuan konsumen layanan RS-AS tentang treatment anti stunting pada anak mengalami peningkatan hingga mencapai $85 \%$.

Pada evaluasi hasil usaha pelayanan jasa RS-AS capaian $70 \%$ pelaksanaan kegiatan, hasilnya menunjukkan bahwa usaha jasa yg RS AS jalankan memberikan keuntungan yang cukup berarti. Hasil keuntungan telah mencapai $61,4 \%$ dari total keuntungan yang telah di tetapkan. Capain persentase keuntungan ini sudah cukup baik mengingat di awal-awal kegiatan kami menggunakan strategi promo dengan pembayaran separuh harga dari masingmasing layanan.

\section{Kesimpulan}

Kegiatan PPUPIK yang dilakukan melalui RS AS telah mmberikan kontribusi yang besar untuk menekan peningkatan angka kejadian stunting terutama di wilayah kerja Puskesmas Bangetayu. Pengabdian masyarakat pada skim PPUPIK dengan usaha penyediaan jasa layanan RS-AS telah mencapai keuntungan sesuai yang ditetapkan.

\section{Ucapan Terima Kasih}

Ucapan rasa terima kasih yang sebesarbesarnya penulis ucapkan kepada Kementrian Riset Teknologi dan Pendidikan Tinggi yang telah memberikan Biaya Pengabdian Masyarakat tahun penerimaan 2019, serta terimakasih kepada Lembaga Penelitian dan Pengabdian Masyarakat Unissula yang telah memfasilitasi dan mendorong penulis dalam melaksanankan pengabdian masyarakat ini hingga selesai dengan baik.

\section{Daftar Pustaka}

[1] Adriana, D., 2011. Tumbuh Kembang dan Therapy Bermain pada anak. Jakarta: Salemba Medika

[2] Ahmed, F., Rahman Khan, M. and Jackson, A. A., 2001. 'Concomitant supplemental vitamin A enhances the response to weekly supplemental iron and folic acid in anemic teenagers in urban Bangladesh', American Journal of Clinical Nutrition, 74(1), pp. 108-115. 2.

[3] Aridiyah, F. O., Rohmawati, N., \& Ririanty, M., 2015. Faktor-faktor yang mempengaruhi kejadian stunting pada anak balita di wilayah pedesaan dan perkotaan. Pustaka Kesehatan, 3(1), 163-170.

[4] Barker, D. J. P. and Thornburg, K. L. (2013) 'Placental programming of chronic diseases, cancer and lifespan: A review', Placenta. Elsevier Ltd, 34(10), pp. 841-845. doi: 10.1016/j.placenta.2013.07.063.

[5] Engebretsen, I., M., S., Jackson, D., Fadnes, L., T., Nankabirwa, V., Diallo, A., H., ......................., \& Nankunda, J., 2014. Growth effects of exclusive breastfeeding promotion by peer counsellors in subSaharan Africa: the cluster-randomised PROMISE EBF trial. BMC Public Health, 14:633. Retrieved from: $\quad \mathrm{http}: / / \mathrm{www}$. biomedcentral.com/1471$2458 / 14 / 633$

[6] Imtihanatun, N., 2013. Faktor risiko balita stunting usia 12-36 bulan di Puskesmas Dasan Agung, Mataram, Provinsi Nusa Tenggara Barat. Public Health and Preventive Medicine Archive, 1(1).

[7] International Food Policy Research Institute., 1999. 'Eradicating Malnutrition: Income Growth or Nutrition Programs?' Available at: http://ebrary.ifpri.org/cdm/ref/collection/p15738coll 2/id/125333. 3.

[8] Kemenkes, 2014. 'Pedoman Gizi Seimbang', Riskesdas, p. 99. 4.

[9] Robert, I., Coppieters, Y., Swennen, B., \& Dramaix, M., 2014. Breastfeeding Duration: A Survival Analysis-Data from a Regional Immunization Survey. BioMed Research International, Volume 2014, Article ID 529790, 8 pages. Retrieved from: http://dx.doi.org/10.1155/2014/529790

[10] Kementerian Koordinator Bidang Kesejahteraan Rakyat (2013) 'Kerangka Kebijakan Gerakan Nasional Percepatan Perbaikan Gizi dalam Rangka Seribu Hari Pertama Kehidupan (Gerakan 1000 HPK)', p. 71.

[11] Mufida, L., Widyaningsih, T. D., \& Maligan, J. M., 2015. Prinsip Dasar MPASI Untuk Bayi Usia 6-24 
Bulan: Kajian Pustaka. Jurnal Pangan dan Agroindustri Vol. 3 No 4 p.1646-1651

[12] Nova, M. \& Afriyanti, O., 2018. Hubungan bert badan, ASI eksklusif, MP-ASI dan asupan energi dengan stunting pada balita usia 24-59 bulan di Puskesmas Lubuk Buaya. Jurnal Kesehatan Perintis, Vol 5(1)

[13] Profil Kesehatan Kota Semarang., 2016. Diakses dari http://depkes.go.id

[14] Profil Kesehatan Provinsi Jawa Tengah., 2016. Diakses dari http://depkes.go.id

[15] Basu, Swastha DH., Irawan. 2008. Manajemen Pemasaran Modern, Edisi II, Cetakan Ke-13, Yogyakarta: Liberty Offset. 